\title{
Asupan gizi dan status gizi vegetarian pada komunitas vegetarian di Yogyakarta
}

Nutrient intake and nutritional status vegetarians among vegetarians in Yogyakarta

Lusia Anggraini ${ }^{1}$, Wiryatun Lestariana ${ }^{2}$, Susetyowati ${ }^{2}$

\begin{abstract}
Background: Vegetarian diet has become a popular diet among people. The information about the benefits of going plant-based as opposed to the risks of degenerative illnesses is widespread and publicly eligible. However, the diet is known to cause the lack of some nutrients such as protein, iron, and $B_{12}$, which has the implication on one's nutritional status. Objective: The study is aimed at identifying nutrient intake and nutritional status vegetarians and the influential factors among vegetarians in Yogyakarta. Method: The study is an observational one with a cross sectional design. It is conducted on vegetarians living in Yogyakarta, which, as methodologically required, involves 102 respondents. The nutritional intake is measured through Food Frequency Questionnaire (FFQ), and the nutritional status through the Body Mass Index status, ferritin serum level, protein serum level and hemoglobin level. The data are analysed using chi square and multiple logistic regression. Results: The mean intake of energy, fat, zinc, vitamin $B_{6}$ and vitamin $B_{12}$ is higher in lactoovo vegetarian while vegan is the higher intake of carbohydrates, protein, iron, folic acid, and vitamin C. Some nutritional intake of less than $80 \%$ of AKG is the intake of energy, carbohydrates, zinc, folic acid, and vitamin $B_{12}$. There are significant differences of the intakes of vitamin $B_{12}$ between both groups. The vegan's IMT is lower than lactoovo vegetarian. Lactoovo vegetarian's protein serum levels are higher, however serum levels of vegan's ferritin and hemoglobin are higher. There are significant differences in serum levels of protein and hemoglobin levels in both groups. There is a significant relation between the intake of iron and hemoglobin levels in vegetarians. Conclusion: Lactoovo vegetarian diet and vegan diet can fulfill the nutritional adequacy, but the things that need to keep in mind are the quality and quantity of food and a good diet plan in order to comply all the nutritional adequacy especially food sources of zinc, folic acid, and vitamin $B_{12 .}$
\end{abstract}

KEY WORDS: body mass index; ferritin; hemoglobin; nutrient intake; protein serum; vegetarian

\begin{abstract}
ABSTRAK
Latar belakang: Pola makan vegetarian telah menjadi pola makan yang mulai banyak dipilih masyarakat seiring dengan meningkatnya pengetahuan masyarakat akan manfaat pola makan berbasis nabati untuk mengurangi risiko terhadap penyakit degeneratif. Pola makan vegetarian rentan kekurangan asupan beberapa zat gizi yaitu protein, zat besi, seng, dan vitamin $\mathrm{B}_{12}$ yang berpengaruh pada status gizi. Tujuan: Penelitian ini bertujuan untuk mengetahui asupan zat gizi dan status gizi vegetarian di komunitas vegetarian Yogyakarta. Metode: Penelitian ini merupakan penelitian observasional dengan rancangan cross sectional. Penelitian ini dilakukan terhadap pelaku pola konsumsi vegetarian yang bertempat tinggal di Yogyakarta yang memenuhi kriteria inklusi. Asupan zat gizi diukur dengan metode Food Frequensi Questionnaire (FFQ), dan status gizi dinilai berdasarkan status indeks masaa tubuh (IMT), kadar serum feritin, serum protein, dan kadar hemoglobin. Data dianalisis dengan uji t , uji korelasi, dan regresi linear ganda. Hasil: Rata-rata asupan energi, lemak, seng, vitamin $\mathrm{B}_{6}$, dan vitamin $\mathrm{B}_{12}$ lebih tinggi pada lakto-ovo vegetarian, sedangkan kelompok vegan lebih tinggi asupan karbohidrat,protein, zat besi, asam folat, dan vitamin $\mathrm{C}$. Beberapa asupan gizi kurang dari $80 \% \mathrm{AKG}$ yaitu asupan energi, karbohidrat, seng, asam folat, dan vitamin $\mathrm{B}_{12}$. Terdapat perbedaan bermakna asupan vitamin $\mathrm{B}_{12}$ antar kedua kelompok. IMT vegan lebih rendah daripada lakto-ovo vegetarian. Kadar serum protein laktovo vegetarian lebih tinggi, sedangkan kadar serum feritin dan kadar hemoglobin vegan lebih tinggi. Terdapat perbedaan bermakna kadar serum protein dan kadar hemoglobin pada kedua kelompok. Terdapat hubungan bermakna asupan zat besi dengan kadar hemoglobin pada vegetarian. Simpulan: Pola diet lakto-ovo vegetarian dan vegan dapat memenuhi sebagian besar kebutuhan gizi dan memiliki status gizi yang baik, namun perlu diperhatikan kualitas dan kuantitas makanan serta perencanaan diet yang baik agar dapat memenuhi semua kecukupan gizi terutama makanan sumber seng, asam folat, dan vitamin $\mathrm{B}_{12 .}$
\end{abstract}

KATA KUNCI: IMT; feritin; hemoglobin; asupan zat gizi; serum protein; vegetarian

\footnotetext{
Korespondensi: Indonesia Vegetarian Society, Perum Taman Duta Mas, Tubagus Angke, Blok A-8, Jakarta Barat, e-mail: hening_yk@yahoo.co.id

${ }^{2}$ Departemen Biokimia, Fakultas Kedokteran Universitas Gadjah Mada

${ }^{3}$ Departemen Gizi Kesehatan, Fakultas Kedokteran Universitas Gadjah Mada
} 


\section{PENDAHULUAN}

Memasuki abad 21, pola makan vegetarian telah menjadi pola makan yang mulai banyak dipilih masyarakat seiring dengan meningkatnya pengetahuan masyarakat akan manfaat pola makan berbasis nabati untuk mengurangi risiko terhadap penyakit degeneratif. Beberapa penelitian epidemiologi menunjukkan keuntungan vegetarian dalam menurunkan risiko penyakit kronis dan degeneratif serta menurunkan angka kematian total. Diet vegan rendah lemak yang dilakukan selama setahun dapat meningkatkan masukan unsur-unsur gizi yang dapat mengurangi resiko penyakit kronis seperti kanker, penyakit kardiovaskuler, diabetes, dan beberapa penyakit degeneratif lainnya serta menurunkan unsur makanan yang dapat meningkatkan resiko terjadinya penyakit kronis $(1,2)$.

Pola makan vegetarian walau memberikan efek yang menguntungkan namun masih banyak anggapan bahwa pola makan vegetarian rentan kekurangan beberapa zat gizi yaitu protein, zat besi, seng, dan vitamin $\mathrm{B}_{12}$. Protein nabati mempunyai protein yang mengandung dalam jumlah kurang satu atau lebih asam amino essensial. Zat besi dalam makanan nabati adalah zat besi non-heme yang proses penyerapannya tergantung pada faktor-faktor luar, seng dapat terhambat penyerapannya oleh fitat dan serat yang banyak pada makanan nabati, sedangkan sumber vitamin $\mathrm{B}_{12}$ sebagian besar berasal dari produk hewani. Kekurangan zat gizi dapat menyebabkan penyakit defisiensi gizi. Penelitian terhadap asupan gizi vegan menunjukkan konsumsi protein dan vitamin $B_{12}$ yang lebih rendah pada vegan. Penelitian lainnya menunjukkan bahwa asupan askorbat secara signifikan lebih tinggi pada kelompok vegan tetapi lebih rendah secara signifikan pada asupan vitamin $\mathrm{B}_{12}$. Penelitian terhadap wanita vegetarian di Australia menunjukkan rata-rata kadar feritin pada vegetarian lebih rendah dibanding non-vegetarian tetapi persentase jumlah responden yang kadar feritin di bawah normal sama antara kelompok vegetarian dan omnivora (3-5).

Masih sedikit penelitian yang meneliti asupan dan status gizi vegetarian di Indonesia. Di tengah meningkatnya kasus-kasus penyakit degeneratif dan semakin meningkatnya animo masyarakat untuk memilih pola konsumsi vegetarian, penelitian ini sangat penting untuk bisa memberi masukan bagi pemerintah, praktisi kesehatan, dan praktisi vegetarian sendiri. Penelitian ini bertujuan untuk mengkaji asupan zat gizi dan status gizi vegetarian serta faktor-faktor yang mempengaruhinya pada komunitas vegetarian di Yogyakarta.

\section{BAHAN DAN METODE}

Penelitian ini merupakan penelitian observasional dengan rancangan cross sectional. Penelitian ini dilakukan terhadap pelaku pola konsumsi vegetarian yang bertempat tinggal di Yogyakarta dan merupakan anggota organisasi Indonesia Vegetarian Society Yogyakarta pada tahun 2014. Sampel dalam penelitian ini adalah anggota organisasi Indonesia Vegetarian Society Yogyakarta yang memenuhi kriteria inklusi dan eksklusi. Kriteria inklusi dalam penelitian ini yaitu berusia 19-64 tahun, sudah menjadi vegetarian baik vegan maupun laktoovo vegetarian minimal 1 tahun, dan bersedia menjadi responden penelitian. Sementara kriteria eksklusi dalam penelitian ini adalah subjek yang sedang hamil/ menyusui, sedang menderita sakit atau menderita penyakit kronis, atau sedang mengonsumsi obat-obatan tertentu, alkohol, dan rokok. Besar sampel dihitung berdasarkan rumus dengan derajat kemaknaan 5\%; proporsi anemia pada komunitas vegetarian di Vihara Bodhicitta Maitreya Yogyakarta sebesar 18\%; kekuatan uji 95\%; dan proporsi perkiraan anemia pada sampel penelitian dengan delta 10\% sehingga jumlah responden penelitian sebanyak 102 orang.

Variabel bebas dalam penelitian ini adalah jenis vegetarian sedangkan variabel terikat adalah asupan zat gizi (energi, karbohidrat, lemak, protein, zat besi, seng, asam folat, vitamin B6, vitamin B12, dan vitamin C) dan status gizi (IMT, kadar serum protein, kadar serum feritin, dan kadar hemoglobin). Sementara variabel luar yang diteliti adalah lama vegetarian. Pengukuran asupan zat gizi dilakukan dengan metode Food Frequency Questionnaire (FFQ). Pengukuran berat badan subjek menggunakan timbangan injak dengan ketelitian $0,1 \mathrm{~kg}$. serta pengukuran tinggi badan dengan menggunakan alat microtoice dengan ketelitian 0,1 cm. Kecukupan asupan zat gizi diketahui dengan cara komputerisasi menggunakan program Nutrisurvey dan hasilnya 
kemudian dibandingkan dengan Angka Kecukupan Gizi (AKG) tahun 2013. Pengukuran kadar $\mathrm{Hb}$ dengan metode photometrik dengan alat photometer. Pengukuran kadar serum feritin dengan metode electrochemiluminescent immunoassay (ECLIA) menggunakan alat Modular E-170. Pengukuran kadar protein total serum dengan metode Calorimetric Assay menggunakan alat Cobas. Data kadar hemoglobin, feritin serum, dan protein total serum dilakukan dengan pemeriksaan laboratorium di Laboratorium Klinik Prodia Yogyakarta. Pengambilan dan preparasi darah subjek dilakukan oleh seorang petugas analis kesehatan dari Laboratorium Klinik Prodia Yogyakarta.

Data dianalisis dengan uji t, uji Pearson korelasi, dan uji regresi linear ganda. Penelitian dilakukan setelah mendapat persetujuan dan ijin dari organisasi IVS, persetujuan dari responden berdasarkan formulir informed consent, dan mendapatkan surat kelayakan etik dari Komisi Etik Penelitian Kedokteran Kesehatan Universitas Gadjah Mada.

\section{HASIL}

Jumlah responden penelitian ini 102 responden yang dibagi menjadi 2 kelompok jenis vegetarian yaitu kelompok lakto-ovo vegetarian sebanyak 70( 69\%) responden dan kelompok vegan $32(31 \%)$ responden. Berimbang jumlah responden laki-laki dan perempuan dengan kelompok umur 19-64 tahun. Sebanyak 61\% responden vegetarian $>5$ tahun dan $39 \%$ vegetarian $\leq$ 5 tahun. Sebagian besar status sebagai mahasiswa dan karyawan.

Tabel 1 menunjukkan rerata asupan energi pada kelompok lakto-ovo vegetarian dan vegan di bawah $80 \%$ AKG. Asupan energi pada lakto-ovo vegetarian lebih tinggi daripada kelompok vegan. Tidak ada perbedaan bermakna $(p=0,639)$ asupan energi dan karbohidrat $(\mathrm{p}=0,911)$. Asupan lemak rata-rata pada kelompok laktoovo vegetarian lebih tinggi daripada kelompok vegan. Namun, tidak ada perbedaan bermakna asupan kedua kelompok $(\mathrm{p}=0,727)$. Rerata asupan protein lebih tinggi pada kelompok vegan $(152,87 \%$ AKG) dibandingkan

Tabel 1. Hasil uji t asupan energi, karbohidrat, lemak, protein, zat besi, seng, asam folat, vitamin $B_{6}$,Vitamin $B_{12}$, dan vitamin $C$ pada kelompok lakto-ovo vegetarian dan vegan di yogyakarta

\begin{tabular}{|c|c|c|c|c|}
\hline Asupan gizi & Jenis vegetarian & Rerata \pm SD (\%) & $\mathbf{t}_{(\mathrm{dn})} / \mathbf{z}$ & $\mathbf{p}$ \\
\hline \multirow{2}{*}{ Asupan energi } & Lakto-ovo vegetarian & $78,41 \pm 26,12$ & \multirow{2}{*}{$0,46_{(100)}$} & \multirow{2}{*}{0,639} \\
\hline & Vegan & $75,87 \pm 23,48$ & & \\
\hline \multirow{2}{*}{ Asupan karbohidrat } & Lakto-ovo vegetarian & $78,06 \pm 28,00$ & \multirow{2}{*}{$-0,11_{(100)}$} & \multirow{2}{*}{0,911} \\
\hline & Vegan & $78,72 \pm 26,51$ & & \\
\hline \multirow{2}{*}{ Asupan lemak } & Lakto-ovo vegetarian & $90,37 \pm 43,03$ & \multirow{2}{*}{$0,35_{(100)}$} & \multirow{2}{*}{0,727} \\
\hline & Vegan & $87,25 \pm 38,88$ & & \\
\hline \multirow{2}{*}{ Asupan protein } & Lakto-ovo vegetarian & $130,58 \pm 78,83$ & \multirow{2}{*}{$-1,78$} & \multirow{2}{*}{0,075} \\
\hline & Vegan & $152,87 \pm 83,80$ & & \\
\hline \multirow{2}{*}{ Asupan zat besi } & Lakto-ovo vegetarian & $95,95 \pm 61,12$ & \multirow{2}{*}{$-1,83_{(100)}$} & \multirow{2}{*}{0,069} \\
\hline & Vegan & $120,65 \pm 66,95$ & & \\
\hline \multirow{2}{*}{ Asupan seng } & Lakto-ovo vegetarian & $56,04 \pm 45,25$ & \multirow{2}{*}{$0,47_{(100)}$} & \multirow{2}{*}{0,640} \\
\hline & Vegan & $52,15 \pm 18,16$ & & \\
\hline \multirow{2}{*}{ Asupan asam folat } & Lakto-ovo vegetarian & $38,50 \pm 36,51$ & \multirow{2}{*}{$-1,41$} & \multirow{2}{*}{0,157} \\
\hline & Vegan & $42,18 \pm 31,93$ & & \\
\hline \multirow{2}{*}{ Asupan vitamin $B_{6}$} & Lakto-ovo vegetarian & $87,21 \pm 38,92$ & \multirow{2}{*}{$-0,188$} & \multirow{2}{*}{0,851} \\
\hline & Vegan & $83,34 \pm 25,53$ & & \\
\hline \multirow{2}{*}{ Asupan vitamin $B_{12}$} & Lakto-ovo vegetarian & $67,41 \pm 47,17$ & \multirow{2}{*}{$-2,02 * *$} & \multirow{2}{*}{$0,044^{*}$} \\
\hline & Vegan & $46,34 \pm 24,25$ & & \\
\hline \multirow{2}{*}{ Asupan vitamin $\mathrm{C}$} & Lakto-ovo vegetarian & $289,34 \pm 194,28$ & \multirow{2}{*}{$-0,37_{(100)}$} & \multirow{2}{*}{0,711} \\
\hline & Vegan & $303,59 \pm 141,42$ & & \\
\hline
\end{tabular}

Asupan zat gizi cukup jika $\geq 80 \%$ AKG; asupan zat gizi kurang jika $<80 \%$ AKG

$\mathrm{t}=\mathrm{t}$-test $; \mathrm{z}=$ nilai $\mathrm{z}$ uji Mann-Whitney; $\mathrm{SD}=$ standar deviasi; $\mathrm{df}=$ derajat bebas;

$*=$ signifikan $\mathrm{p}<0,05 ; * *=\mathrm{z}_{\text {hitung }}>\mathrm{z}_{\text {tabel }}$ 
Lusia Anggraini, dkk: Asupan gizi dan status gizi vegetarian pada komunitas vegetarian di Yogyakarta

Tabel 2. Indeks massa tubuh pada lakto-ovo vegetarian dan vegan di Yogyakarta

\begin{tabular}{|c|c|c|c|c|c|c|c|c|c|}
\hline \multirow{3}{*}{ Jenis vegetarian } & \multicolumn{6}{|c|}{ Status IMT } & \multicolumn{2}{|c|}{ Total } & \multirow{3}{*}{$\mathbf{p}$} \\
\hline & \multicolumn{2}{|c|}{ Cukup } & \multicolumn{2}{|c|}{ Kurus } & \multicolumn{2}{|c|}{ Gemuk } & \multirow{2}{*}{$\mathbf{n}$} & \multirow{2}{*}{$\%$} & \\
\hline & $\mathrm{n}$ & $\%$ & $\mathbf{n}$ & $\%$ & $\mathrm{n}$ & $\%$ & & & \\
\hline Lakto-ovo vegetarian & 42 & 60 & 8 & 11 & 20 & 29 & 70 & 100 & \\
\hline Vegan & 21 & 66 & 4 & 12 & 7 & 22 & 32 & 100 & 0,815 \\
\hline Total & 63 & & 12 & & 27 & & 102 & & \\
\hline
\end{tabular}

Tabel 3. Hasil pemeriksaan kadar serum protein, serum feritin, dan hemoglobin pada kelompok laktoovo vegetarian dan kelompok vegan

\begin{tabular}{|c|c|c|c|c|c|}
\hline \multirow{3}{*}{ Kadar serum } & \multicolumn{4}{|c|}{ Jenis vegetarian } & \multirow{3}{*}{$\mathbf{p}$} \\
\hline & \multicolumn{2}{|c|}{$\begin{array}{l}\text { Lakto-ovo } \\
\text { vegetarian }\end{array}$} & \multicolumn{2}{|c|}{ Vegan } & \\
\hline & $\mathrm{n}$ & $\%$ & $\mathbf{n}$ & $\%$ & \\
\hline \multicolumn{6}{|l|}{ Protein total } \\
\hline Protein kurang & 0 & 0 & 0 & 0 & - \\
\hline Protein normal & 70 & 100,0 & 32 & 100,0 & \\
\hline \multicolumn{6}{|l|}{ Feritin serum } \\
\hline Deplesi Besi & 5 & 7,1 & 0 & 0 & 0,322 \\
\hline Normal & 65 & 92,9 & 32 & 100 & \\
\hline \multicolumn{6}{|l|}{ Hemoglobin } \\
\hline Hb kurang & 4 & 5,7 & 1 & 3,1 & 1,000 \\
\hline Hb normal & 66 & 94,3 & 31 & 96,9 & \\
\hline
\end{tabular}

kelompok lakto-ovo vegetarian (130,58\% AKG), tetapi tidak menunjukkan perbedaan bermakna $(\mathrm{p}=0,075)$ dan kedua kelompok mempunyai asupan di atas 100\% AKG. Kelompok vegan rata-rata mempunyai asupan zat besi yang lebih tinggi yaitu 120,65 \% AKG dibanding kelompok lakto-ovo vegetarian $(95,95 \%$ AKG). Kedua kelompok mempunyai asupan di atas $80 \%$ AKG tetapi tidak ada perbedaan bermakna $(p=0,069)$ asupan zat besi pada kedua kelompok.

Status gizi responden berdasarkan IMT menunjukkan bahwa sebagian besar responden memiliki IMT normal baik ada kelompok lakto-ovo vegetarian (60\%) maupun kelompok vegan (66\%) (Tabel 2). Terdapat 8 responden yang mempunyai IMT kurus pada kelompok lakto-ovo vegetarian dan 4 responden pada kelompok vegan. Sebanyak $28,6 \%$ responden dari kelompok lakto-ovo vegetarian dan 21,9\% dari kelompok vegan yang dikategorikan gemuk. Tidak ada perbedaan bermakna $(\mathrm{p}=0,815)$ IMT antara dua kelompok. Ratarata IMT kelompok lakto-ovo vegetarian lebih tinggi $(25,17)$ dibanding dengan kelompok vegan $(22,65)$. Hasil uji Mann-Whitney menunjukkan tidak ada perbedaan bermakna antara kedua kelompok.

Tabel 3 memperlihatkan bahwa kadar protein dalam darah menunjukkan tidak ada kadar protein yang kurang pada kelompok lakto-ovo vegetarian maupun kelompok vegan. Kadar serum protein kelompok laktoovo lebih tinggi dibanding kelompok vegan. Demikian juga kadar serum feritin dalam darah responden juga sebagian besar memperlihatkan nilai normal yaitu 92,9\% pada kelompok lakto-ovo vegetarian dan $100 \%$ pada kelompok vegan. Sebanyak 5 responden mempunyai nilai kadar serum feritin kurang pada kelompok lakto-ovo vegetarian. Rata-rata kadar serum feritin ada vegan lebih tinggi dibanding kelompok lakto-ovo vegetarian.

Lebih lanjut, sebagian besar responden mempunyai kadar $\mathrm{Hb}$ normal yaitu 94,3\% pada lakto-ovo vegetarian dan $96,9 \%$ pada kelompok vegan. Ada 4 responden yang menderita anemia pada kelompok lakto-ovo vegetarian dan 1 responden dari kelompok vegan. Rata-rata kadar $\mathrm{Hb}$ pada kelompok vegan lebih tinggi daripada kelompok lakto-ovo vegetarian. Hasil uji Chi-Kuadrat menunjukkan tidak ada perbedaan bermakna. Rata-rata kadar protein serum responden yang vegetarian kurang dari 5 tahun lebih tinggi dibanding dengan yang vegetarian lebih dari lima tahun dan menunjukkan ada perbedaan yang signifikan antara dua kelompok. Responden yang vegetarian kurang dari 5 tahun mempunyai rata-rata kadar feritin lebih tinggi dibanding dengan yang vegetarian lebih dari lima tahun tetapi tidak ada perbedaan yang signifikan antara dua kelompok.

\section{BAHASAN}

Hasil penelitian ini menunjukkan bahwa kelompok lakto-ovo mempunyai rerata asupan gizi yang lebih tinggi pada energi, lemak, seng, vitaminB ${ }_{6}$, dan vitamin $B_{12}$. Kelompok vegan mempunyai rata-rata asupan yang lebih tinggi pada karbohidrat, protein, zat besi, 
asam folat, dan vitamin C. Asupan rendah pada zat gizi seng, asam folat, dan vitamin $\mathrm{B}_{12}$ baik pada lakto-ovo vegetarian maupun vegan. Terdapat perbedaan bermakna asupan vitamin $\mathrm{B}_{12}$ antara kedua kelompok. Vitamin $\mathrm{B}_{12}$ banyak pada sumber makanan hewani. Pada kelompok lakto-ovo masih mengonsumsi makanan sumber hewani yaitu susu dan telur sedangkan pada vegan sama sekali tidak mengkonsumsi sumber makanan hewani sehingga berpotensi terjadinya defisiensi vitamin $B_{12}$ pada jangka panjang.

Status gizi orang dewasa dalam penelitian ini ditentukan dengan mengukur IMT dan pengukuran kadar hemoglobin, serum feritin, dan serum protein secara laboratorium. Rerata IMT kelompok vegan yaitu 22,65, lebih rendah daripada kelompok lakto-ovo vegetarian 25,17 . Penelitian yang dilakukan EPIC-Oxford terhadap beberapa kelompok yang mempunyai pola diet yang berbeda menunjukkan berat badan rata-rata kelompok vegan lebih rendah daripada kelompok lainnya. Penelitian lainnya juga menunjukkan bahwa kadar IMT pada kelompok vegan Africans American lebih rendah daripada kelompok lakto-ovo vegetarian $(6,7)$.

Lebih rendahnya IMT pada kelompok vegan didukung oleh asupan lemak yang lebih rendah pada kelompok vegan dibanding kelompok lakto-ovo vegetarian. Makanan vegan lebih rendah lemak daripada lakto-ovo vegetarian karena sumber lemak makanan vegan berasal dari nabati yang sebagian besar adalah lemak tak jenuh. Satu gram lemak dapat menghasilkan 9 kkal sedangkan satu gram karbohidrat menghasilkan 4,1 kkal dan satu gram protein menghasilkan 4,1 kkal. Asupan karbohidrat dan protein pada vegan lebih tinggi daripada lakto-ovo vegetarian, namun karena jumlah kalori yang dihasilkan dari karbohidrat dan protein lebih rendah dibanding lemak, maka asupan energi vegan lebih rendah daripada lakto-ovo vegetarian. Hal ini mendukung IMT vegan lebih rendah dibanding laktoovo vegetarian.

Hasil pemeriksaan protein serum menunjukkan nilai protein serum semua responden berada pada nilai cukup. Hal ini didukung oleh rata-rata asupan protein kedua kelompok di atas 100\% AKG. Rata-rata protein serum kelompok lakto-ovo vegetarian lebih tinggi daripada kelompok vegan dan berbeda secara bermakna.
Sementara asupan protein kelompok vegan lebih tinggi daripada kelompok lakto-ovo vegetarian. Sumber protein pada kelompok vegan hanya dari nabati yaitu biji-bijian dan kacang-kacangan sedangkan kelompok lakto-ovo vegetarian masih mengkonsumsi protein hewani dari telur dan susu yang mengandung protein dengan nilai kecernaan yang lebih tinggi. Pada kelompok vegan walaupun mempunyai asupan protein lebih tinggi tetapi protein nabati umumnya mempunyai nilai kecernaan yang lebih rendah sehingga status protein serum vegan sedikit lebih rendah dibanding lakto-ovo vegetarian walau asupannya lebih tinggi (8).

Nilai feritin terutama ditentukan oleh asupan zat besi pada tubuh.Lebih tingginya kadar feritin pada vegan didukung oleh asupan besi pada kelompok vegan yang melebihi $100 \%$ AKG dan mempunyai perbedaan yang mendekati nilai signifikan dibanding kelompok laktoovo vegetarian. Makanan nabati mengandung banyak zat besi, namun zat besi yang terdapat pada makanan nabati adalah zat besi nonheme yang sesungguhnya lebih sulit diserap di usus. Selain itu sebagian makanan nabati mengandung fitat, polifenol, dan serat yang dapat menghambat penyerapan zat besi. Di sisi lain, makanan vegetarian mengandung banyak vitamin $\mathrm{C}$ yang dapat membantu penyerapan zat besi di Pada penelitian ini asupan vitamin $\mathrm{C}$ kedua kelompok cukup tinggi dan asupan vitamin $\mathrm{C}$ pada vegan lebih tinggi dibanding kelompok lakto-ovo vegetarian. Tingginya konsumsi vitamin $C$ pada vegetarian sangat membantu dalam proses penyerapan zat besi nonheme pada vegetarian (9).

Asupan protein hewani sangat membantu proses penyerapan zat besi. Sumber protein kelompok lakto-ovo vegetarian yang masih mengandung protein hewani dapat membantu penyerapan zat besi nonheme sehingga dapat meningkatkan zat besi dalam darah. Beberapa makanan sumber protein nabati seperti kacang kedelai dan legum, walaupun mengandung fitat dan polifenol yang dapat menghambat penyerapan zat besi, namun keberadaan protein nabati seperti pada tempe dapat mencegah terjadinya hambatan penyerapan itu. Hal ini membawa keuntungan bagi vegan yang mempunyai asupan protein yang tinggi yang sebagian besar dari tempe (10).

Kadar $\mathrm{Hb}$ merupakan salah satu parameter yang digunakan secara luas untuk menetapkan prevalensi 
anemia. Hasil penelitian menunjukkan rata-rata kadar hemoglobin kedua kelompok berada pada nilai normal. Rata-rata kadar hemoglobin pada vegan lebih tinggi daripada kelompok lakto-ovo vegetarian dan mempunyai perbedaan bermakna. Lebih tingginya kadar hemoglobin pada vegan didukung oleh beberapa asupan zat gizi yang lebih tinggi pada vegan antara lain asupan protein, zat besi, asam folat, dan vitamin C. Asupan protein kelompok vegan lebih tinggi daripada kelompok lakto-ovo vegetarian. Kedua kelompok mempunyai asupan protein di atas $100 \%$ AKG. Hal ini didukung dari pemeriksaan kadar protein serum dengan nilai cukup. Protein serum penting dalam proses pembentukan hemoglobin karena proses pembentukan heme membutuhkan protein dan globin sendiri juga adalah unsur protein. Kekurangan protein dapat menyebabkan terjadinya anemia.

Lebih lanjut, zat besi merupakan zat utama dalam pembentukan heme. Asupan zat besi pada kedua kelompok menunjukkan nilai di atas 80\% AKG. Asupan zat besi kelompok vegan lebih tinggi dibanding kelompok lakto-ovo vegetarian, dan terlihat dari lebih tingginya kadar serum feritin pada kelompok vegan. Asupan asam folat pada penelitian ini tergolong rendah pada dua kelompok responden yaitu di bawah $80 \%$ AKG. Penelitian lain menunjukkan kadar folat yang tinggi pada vegan sedangkan pada lakto ovo vegetarian lebih rendah. Tidak ada perbedaan bermakna pada kedua kelompok responden pada penelitian ini (11). Seng diperlukan dalam fungsi berbagai enzim dalam proses metabolisme. Dalam sintesa heme, seng diperlukan dalam sintesa $\delta A L A$ dehydratase yang juga diperlukan dalam sintesa heme sehingga kekurangan seng juga dapat menyebabkan anemia. Asupan seng kedua kelompok di bawah $80 \%$ AKG.

Asupan vitamin $\mathrm{B}_{6}$ pada kedua kelompok di atas 80\% AKG. Kelompok lakto-ovo vegetarian mempunyai asupan lebih tinggi daripada kelompok vegan. Dalam proses sintesis heme, vitamin $\mathrm{B}_{6}$ berperan dalam pembentukan suksinil-KoA dan glisin dan diperlukan dalam sintesa enzim $\delta$-aminolevulinic acid synthase, suatu enzim yang berperan dalam proses pembentukan heme sehingga kekurangan vitamin $B_{6}$ juga dapat menyebabkan anemia. Rata-rata asupan vitamin $\mathrm{B}_{12}$ pada kedua kelompok dibawah $80 \%$ AKG. Kelompok vegan mempunyai asupan vitamin $\mathrm{B}_{12}$ lebih rendah dibanding kelompok lakto-ovo vegetarian. Terdapat perbedaan yang bermakna pada kedua kelompok. Vitamin $\mathrm{B}_{12}$ banyak terdapat pada sumber makanan hewani. Pada kelompok lakto-ovo vegetarian masih mengkonsumsi sumber makanan hewani yaitu susu dan telur. Pada kelompok vegan sama sekali tidak mengkonsumsi sumber makanan hewani sehingga berpotensi terjadinya defisiensi vitamin $B_{12}$ dalam jangka panjang. Penelitian di Riau menunjukkan bahwa kelompok lakto-ovo vegetarian juga berpotensi kekurangan vitamin $\mathrm{B}_{12}$ jika tanpa asupan sumber makanan vitamin $B_{12}$ yang cukup (12).

Rendahnya beberapa asupan zat gizi antara lain seng, asam folat, vitamin $\mathrm{B}_{12}$ dalam jangka panjang berpotensi menyebabkan terjadinya anemia dan harus menjadi perhatian bagi pada pelaku vegetarian dalam menyusun komposisi makanan. Berdasarkan hasil uji statistik, asupan zat besi berhubungan dengan kadar serum feritin dengan kekuatan hubungan sedang. Sebagian besar zat besi dalam tubuh dipergunakan untuk membentuk sel darah merah. Sedangkan kelebihan zat besi dalam tubuh akan disimpan sebagai feritin, hemosiderin, limpa, dan sum-sum tulang belakang. Kekurangan asupan zat besi dalam darah menyebabkan penggunaan cadangan zat besi dan dalam jangka panjang akan dapat menurunkan kadar serum feritin, demikian juga sebaliknya peningkatan asupan zat besi akan meningkatkan kadar serum feritin (13).

Asupan zat besi memegang peranan penting dalam menentukan kadar hemoglobin. Dua per tiga kandungan zat besi dalam tubuh berbentuk hemoglobin. Asupan zat besi yang kurang berpotensi terjadinya anemia. Dalam penelitian ini menunjukkan ada hubungan bermakna antara asupan zat besi dengan kadar hemoglobin pada kekuatan hubungan sedang dengan koefisien korelasi o,45. Penelitian di Bali menunjukkan korelasi yang kuat dan bermakna antara asupan zat besi dengan kadar hemoglobin. Semakin tinggi asupan zat besi, semakin rendah kemungkinan terjadinya anemia atau semakin tinggi kadar hemoglobin (14).

Defisiensi dalam tubuh terbagi dalam tiga tahap. Tahap pertama yaitu berkurangnya simpanan zat besi dalam hati tetapi belum mempengaruhi pembentukan sel darah merah (deplesi besi). Tahap kedua yaitu berkurangnya zat besi yang tersedia untuk sistem 
eritropoiesis yaitu pembentukan sel-sel darah merah dalam sum-sum tulang. Pada tahap ini nilai $\mathrm{Hb}$ masih normal atau mungkin turun sedikit. Tahap ketiga adalah keadaan ketika kadar hemoglobin sudah menurun dan terjadinya anemia. Uji multivariat menunjukkan hubungan yang erat dan bermakna antara asupan zat besi dengan kadar hemoglobin $(\mathrm{p}=0,000)(15)$.

Semakin berkurangnya status gizi seseorang seiring dengan semakin lamanya vegetarian kemungkinan disebabkan oleh semakin longgarnya pengaturan makanan para pelaku vegetarian. Sebagian besar responden yang lebih dari 5 tahun vegetarian adalah kelompok pekerja sebagai karyawan yang mempunyai pengaturan makanan yang longgar dan seadanya. Hasil penelitian ini menunjukkan perlunya pengaturan dan perencanaan makanan yang lebih baik walaupun seseorang semakin lama menjalani vegetarian. Pengaturan makan yang baik akan menjamin tetap terpenuhinya asupan zat gizi yang akan mempengaruhi status gizi vegetarian.

\section{SIMPULAN DAN SARAN}

Pola diet lakto-ovo vegetarian dan vegan dapat memenuhi kecukupan asupan gizi karbohidrat, lemak, protein, zat besi, vitamin $\mathrm{B}_{6}$, dan vitamin $\mathrm{C}$. Namun, asupan seng, asam folat, dan vitamin $\mathrm{B}_{12}$ belum mencapai $80 \%$ AKG. Kelompok vegan perlu memperhatikan asupan vitamin $B_{12}$ dengan menambah asupan tempe, suplemen vitamin $\mathrm{B}_{12}$, atau makanan dengan fortifikasi vitamin $\mathrm{B}_{12}$. Dengan perencanaan dan pengaturan makanan yang baik agar semua asupan gizi yang dibutuhkan tubuh dapat terpenuhi melalui makanan sehari-hari yang dikonsumsi.

\section{RUJUKAN}

1. Sabate J. The contribution of vegetarian diets to health and disease: a paradigm shift. Am J Clin Nutr 2003;78:502S7S.

2. Dewell A, Weidner G, Sumner MD, Chi CS, Ornish D. A very low fa vegan diet increases intake of protective dietary factors and decreases intake of pathogenic dietary factors. J Am Diet Assoc 2008 Feb;108(2):347-56.
3. Abdulla M, Andersson I, Asp NG, Berthelsen K, Birkhed D, Ockerman PA, et al. Nutrient intake and health status of vegans: chemical analyses of diets using the duplicate portion sampling technique. Am J Clin Nutr 1981;34(11):2464-77.

4. Haddad EH, Berk LS, Kettering JD, Hubbard RW, Peters WR. Dietary intake and biochemical,hematologic,and immune status of vegans compared with nonvegetarians. Am J Clin Nutr 1999;70(3 Suppl):586S-93S.

5. Ball MJ, Bartlett MA. Dietary intake and iron status of australian vegetarian women. Am J Clin Nutr 1999; 70(3):353-8.

6. Rosell M, Appleby P, Spencer E, Key T. Weight gain over 5 years in 21. 966 meat-eating, fish-eating, vegetarian, and vegan men and women in EPIC-Oxford. Int J Obes (Lond) 2006;30(9):1389-96.

7. Toohey ML, Harris MA, DeWitt W, Foster G, Schmidt WD, Melby CL. Cardiovascular disease risk factors are lower in african-american vegans compared to lacto-ovo -vegetarian. J Am Coll Nutr 1998;17(5):425-34.

8. Linder MC. Biokimia nutrisi dan metabolisme. Jakarta: Universitas Indonesia Press; 2006.

9. DeBruyne LK, Pinna K, Whitney E. Nutrition and diet therapy. Belmont: Thomson Wadsworth; 2008.

10. Baynes RD, Stipanuk MH. Iron. In : Stipanuk, M.H. ed. Biochemical and physiological aspects of human nutrition. Philadelphia: Saunders; 2000.

11. Gilsing AM, Crowe FL, Lloyd-Wright Z, Sanders TA, Appleby PN, Key TJ, et al. Serum concentrations of vitamin $\mathrm{B} 12$ and folate in British male omnivores, vegetarians and vegans: results from a cross-setional analysis of the EPIC-Oxford cohort study. Eur J Clin Nutr 2010;64(9):933-9.

12. Susianto. Peran formula tempe sebagai sumber vitamin $\mathrm{B}_{12}$ dan implementasinya untuk diet vegetarian [Disertasi]. Jakarta: Universitas Indonesia; 2011.

13. Dallma PR. Iron. In: Brown ML. ed. Present knowledge in nutrition. $6^{\text {th }}$ ed. Washington: International Life Sciences Institute (ILSI) Press; 1990.

14. Widarini NP. Asupan zat gizi dan kejadian anemia pada remeja putri vegetarian di Kabupaten Badung Propinsi Bali [Tesis]. Fakultas Kedokteran: Universitas Gadjah Mada; 2008.

15. Hillman RS, Ault KA, Rinder HM. Iron deficiency anemia. In: Hillman RS, Ault KA, Rinder HM, ed. Hematology ini clinical practice. New York: McGraw Hill; 2005. 